\title{
Two-signal blockade with anti-CD45RB and anti-CD154 monoclonal antibodies inhibits graft rejection via CD4-dependent mechanisms in allogeneic skin transplantation
}

\author{
Eun-Young $\mathrm{Kim}^{1 *}$, Eun-Na Lee ${ }^{1 *}$, \\ Jienny Lee ${ }^{1}$, Hae-Jung Park', \\ Chi-Young Chang ${ }^{1}$, Da-Yeon Jung ${ }^{1}$, \\ Su-Young Choi ${ }^{1}$, Suk-Koo Lee ${ }^{2}$, \\ Jae-Won $\mathrm{Joh}^{2}$ and Sung-Joo Kim ${ }^{1,2,3}$ \\ ${ }^{1}$ Transplantation Research Center \\ ${ }^{2}$ Department of Surgery \\ Samsung Medical Center \\ Sungkyunkwan University School of Medicine \\ Seoul 135-710, Korea \\ ${ }^{3}$ Corresponding author: Tel, 82-2-3410-3476; \\ Fax, 82-2-3410-0040; E-mail, kmhyj@smc.samsung.co.kr \\ ${ }^{*}$ These authors contributed equally to this work.
}

Accepted 2 June 2006

Abbreviations: CFSE, carboxyfluorescein diacetate succinimidyl ester; CTLA-4, cytotoxic $\mathrm{T}$ lymphocyte antigen 4; mAb, monoclonal antibody

\begin{abstract}
Blockade of signal 1 or 2 for T-cell activation by the use of anti-CD45RB and anti-CD154 monoclonal antibodies (mAb) (two-signal blockade) has been proven effective in preventing or delaying graft rejection. However, the mechanisms of its immunomodulatory effects are clearly unknown and the present studies were performed to determine how the two-signal blockade modulate allogeneic immune responses, especially T-cell mediated cellular im munity, in a murine skin allograft model. We now report on the profound inhibition of alloreactive $T$ cells by two-signal blockade via CD4-dependent mechanisms. C57BL/6 mice of BALB/c skin allograft were treated with anti-CD45RB, anti-CD154, CTLA4Ig, or their combinations. For depletion of CD4 or CD8 $T$ cells, the recipients received CD4-depleting or CD8-depleting mAb. We confirmed that survival of skin allograft was markedly prolongated in the two-signal blockade-treated group. In depletion study, anti-CD45RB, anti-CD154 and CD4-depleting mAb-treated group showed acute rejection of skin allograft in contrast to CD8-depleting group treated
\end{abstract}

with the two-signal blockade. In the group treated with the two-signal blockade, the proportions of $\mathrm{CD}^{+}{ }^{+} \mathrm{CD} 45 \mathrm{RB}^{\text {low }}$ and $\mathrm{CD8}{ }^{+} \mathrm{CTLA}-4$ regulatory $T$ cells were increased while effector $\mathrm{CDB}^{+} \mathrm{T}$ cells, including IFN- $\gamma$-secreting and $\mathrm{CD}^{+}{ }^{+} \mathrm{CD} 62 \mathrm{~L}^{\text {low }} \mathrm{T}$ cells, were decreased when compared with non-treated group. In contrast, the CD4-depleted group treated with the two-signal blockade resulted in recovery from immunoregulatory effects of two-signal blockade. In addition, results of IL-4 and IL-10 production were also showed CD4-dependence. Therefore, the twosignal blockade is accompanied by CD4-dependent mechanisms in allogeneic skin transplantation.

Keywords: antigens, CD45; CD40 ligand; transplantation, homologous; skin transplantation; CD4positive T-lymphocytes

\section{Introduction}

The generation of anti-donor-specific $T$ cells that migrate into the graft is an essential component of most rejection processes in allogeneic transplantation (Tilney NL et al., 1991). Blockade of signal 1 or 2 of T-cell activation by the use of biological modifiers such as monoclonal antibodies (mAb) and soluble receptor ligand has proved effective in preventing or delaying graft rejection (Lazarovits Al et al., 1996; Basadonna GP et al., 1998; Rothstein DM et al., 2001). CD45 is a protein tyrosine phosphatase expressed by all nucleated hematopoietic cells. It plays a crucial role in $\mathrm{T}$ cell activation by regulating the activity of src-family protein tyrosine kinases and their substrates (Trowbridge IS et al., 1994). Genetic studies have shown that a single CD45 gene produces four different isoforms by alternative splicing of three exons. Among the isoforms of CD45, CD45RB contains B-exon in variable $\mathrm{N}$-terminal and can be detected by anti-CD45RB (Hathcock KS et al., 1992). Modulation of signal 1 by administration of anti-CD45RB has shown efficacy in preventing kidney (Lazarovits Al et al., 1996), pancrease (Davies JD et al., 1999), and islet allograft rejection in murine models (Auersvald LA et al., 1997; Basadonna GP et al., 1998; Rothstein DM et al., 2001; Fecteau S et al., 2001). CD154 (CD40L) is a tumor necrosis factor receptor family member 
involved in T-cell costimulation (signal 2) after antigen recognition. Blockade of signal 2 by selectively targeting co-stimulatory molecules has also yielded promising results in modulating immune responses. Treatment with anti-CD154 induced long-term allograft acceptance in several transplantation models (Kirk AD et al., 1997; Kirk AD et al., 1999; Kenyon NS et al., 1999 ; Kenyon NS and Fernandez LA et al., 1999).

The therapeutic combination designed to block signal 1 and 2 using anti-CD45RB and anti-CD154 has been developed in murine stringent transplant models, where $\mathrm{CD}^{+} \mathrm{T}$ cells were depleted from lymphoid organs and inhibited from infiltration in graft. Even C57BL/6 mice, which are resistant to CD40L/CD28 costimulation blockade with anti-CD154 plus cytotoxic $T$ lymphocyte antigen 4-lg (CTLA4-Ig) (Williams MA et al., 2000), enjoyed an expansion of islet cells and skin allograft survival with the combined treatment (Rothstein DM et al., 2001). Accordingly, two-signal blockade with antiCD45RB plus anti-CD154 may be potentially used as a treatment regimen for tolerance induction in clinical transplantation. However, the mechanisms by which two-signal blockade efficiently modulate allogeneic immune responses are clearly unknown and it is necessary to uncover its mechanisms for bases of large animal and further clinical studies.

In this study, we performed to determine how two-signal blockade modulates immune responses, focusing on allogeneic responses of $T$ cells, in a murine allogeneic skin transplantation model, and demonstrate that two-signal blockade contributes to suppress allogeneic responses both in vitro and in vivo, and requires CD4-dependent mechanism of alloreactive CD8 activation.

\section{Materials and Methods}

\section{Mice}

Adult male 8-week-old C57BL/6 $\left(\mathrm{H}-2^{\text {b }}\right)$ recipient and BALB/c $\left(\mathrm{H}-2^{\mathrm{d}}\right)$ donor mice (Jackson Laboratories, Bar Harbor, ME) were housed in specific pathogen free conditions and in accordance with the principles of laboratory animal care and guide for the use of laboratory animals in our institution.

\section{Skin transplantation}

Full thickness skin grafts $\left(\sim 1 \mathrm{~cm}^{2}\right)$ from donors were transplanted on the dorsal thorax of recipient mice and secured with a band-aid for 7 days. Graft survival was then followed by daily visual inspection. Rejection was defined as the complete loss of viable epidermal graft tissue.

\section{Treatment protocols}

C57BL/6 recipient mice received anti-CD45RB (HB220; $100 \mu \mathrm{g} /$ mice, Bioexpress, Lebanon, NH) combined with/without hamster anti-mouse antiCD154 (CD40L) (MR1; $250 \mu \mathrm{g} / \mathrm{mice}$, Bioexpress, Lebanon, $\mathrm{NH}$ ) by i.p. on the day of skin transplantation (day 0 ) and on postoperative days 2, 4, 6 and 8 . The compared group was treated with anti-CD154 plus CTLA4-lg (250 $\mu \mathrm{g} /$ mice, Bioexpress, Lebanon, $\mathrm{NH}$ ) by the same manner as mentioned above. Rat anti-mouse CD4 (GK1.5) and CD8 (2.43) depleting mAb (100 $\mu \mathrm{g} /$ mice, Bioexpress, Lebanon, $\mathrm{NH}$, respectively) were administered to the recipients on days $-2,-1$ and 0 before transplantation and given every week until the day of graft rejection. Control recipients were treated with relevant doses of rat IgG (Bioexpress, Lebanon, $\mathrm{NH}$ ).

\section{Cell preparation}

Spleens were removed aseptically from mice and prepared in a single-cell suspension by gently rubbing the tissue through a $40 \mu \mathrm{m}$ nylon filter. The lysis of red blood cells (RBC) was conducted with a lysing kit (R\&D Systems, Minneapolis, MN).

\section{Flow cytometry}

Phenotypic analysis of isolated splenocytes was performed by using immunofluorescence technique. All antibodies were purchased from BD Pharmingen (San Diego, CA). For the subtypes of $T$ cells, we used FITC-, PE-, and PE-Cy5-conjugated anti-mouse CD3, CD4, CD8, CD45RB, CD62L, CD69, CD152 (CTLA-4), and IFN- $\gamma$. Analyses of 5-(and-6)-carboxyfluorescein diacetate, succinimidyl ester (CFSE)-labeled $\mathrm{T}$ cells of irradiated recipients were conducted by splenocytes with APC-conjugated anti-mouse CD4 and CD8 antibodies. Negative controls used mouse or rat IgG fluorchrome conjugates of appropriate isotype. Cells were stained in various combinations on ice for $30 \mathrm{~min}$. After washing, threecolor flow cytometry was performed on a FACSVantage (BD Biosciences, Mountain View, CA). Cells in lymphocyte gate and stained positive for CD4 or CD8 were analyzed for their subset. The data were analyzed using CellQuest software (Becton Dickinson, Braintree, MA).

\section{CFSE labeling and adoptive transfers}

Splenocytes were harvested from C57BL/6 recipient mice untreated or treated with mAb on 10 days posttransplant. After RBC lysis and nylon wool passage, the cells were incubated with $10 \mu \mathrm{M}$ CFSE in RPMI 1640 (Molecular Probes, Eugene, OR). After incubation for $10 \mathrm{~min}$, the staining was halted 
by the addition of cold RPMI 1640. BALB/c mice were irradiated with 1800 rads prior to transfer of C57BL/6 allogeneic T cells (C57BL/6 mice received 1800 rads for syngeneic transfers). Irradiated $\mathrm{BALB} / \mathrm{C}$ or $\mathrm{C} 57 \mathrm{BL} / 6$ mice then received $2 \times 10^{7}$ CFSE-labeled cells by penile vein injection. Splenocytes were harvested on day 3 post-transfer, stained for expression of CD4 and CD8, and gated for positive populations.

\section{Determination of precursor frequencies}

Precursor frequency was determined as previously described (Trambley $\mathrm{J}$ et al., 1999). In short, peaks were numbered for the number of times the cells had divided ( $n$ ). A T cell that divides $n$ times generates $2^{n}$ daughter cells and, therefore, the number of cells in that peak is divided by $2^{n}$ in order to obtain the number of precursors for each individual peak. For allogeneic transfers, the precursor numbers of peaks 4-8 were added together and divided by the total number of initial precursors to generate a precursor frequency for divisions 4-8. These divisions were chosen based on the observation that syngeneic transferred cells do not proceed detectably beyond three divisions.

\section{IFN- $\gamma$ ELISPOT assays}

Allospecific T-cell responses were measured by IFN- $\gamma$ ELISPOT assays using splenocytes from experimental C57BL/6 mice on days 10 and 22 after skin transplantation. Ester-cellulose-bottom plate (Millipore, Bedford, MA) was coated with rat antimouse IFN- $\gamma$ (BD Pharmingen, San Diego, CA) $(4 \mu \mathrm{g} / \mathrm{ml}$ in phosphate buffered saline (PBS, $\mathrm{pH} 7.2)$, $100 \mu \mathrm{l} /$ well) at $4^{\circ} \mathrm{C}$ overnight. After washing, various dilutions of effector cells were added. Donor BALB/C splenocytes as stimulator were irradiated (2000 rads) and added at $1: 10$ ratio of stimulators to effectors. Effector cells were incubated for 14-16 h at $37^{\circ} \mathrm{C}$ with/ without stimulators and then biotinylated anti-mouse IFN- $\gamma(4 \mu \mathrm{g} / \mathrm{ml}$ in PBS, $100 \mu \mathrm{l}$ per well, Pharmingen, San Diego, CA) was added. After incubation for $2-3 \mathrm{~h}$ at $4{ }^{\circ} \mathrm{C}$, unbound antibody was removed and horseradish peroxidase-avidin $D$ (Sigma, St. Louis, MO) was added. Spots were developed with the substrate 3-amino-9-ethyl-carbazole (Sigma, St. Louis, MO) with $0.015 \% \mathrm{H}_{2} \mathrm{O}_{2}$. Each spot represents an IFN- $\gamma$-secreting cell. The frequency was determined by dividing the number of spots counted in each well by the total number of cells plated at that dilution.

\section{Cytokine production}

A total of $2 \times 10^{5}$ splenocytes cells/well in 96 -well plates that had been precoated with $5 \mu \mathrm{g} / \mathrm{ml}$ anti-CD3 was incubated in $200 \mu \mathrm{l}$ RPMI1640 medium supplemented with $10 \%$ fetal bovine serum and $2 \mu \mathrm{g} / \mathrm{ml}$ anti-CD28 for $72 \mathrm{~h}$. Cell-free culture supernatants were collected after $72 \mathrm{~h}$, and the cytokine levels were assayed by ELISA using respective cytokine standards for the detection of IL-4 and IL-10 according to the manufacturer's directions. Cytokines were detected by adding HRPlabeled streptavidin followed by washing and addition of tetramethyl benzidine- $\mathrm{H}_{2} \mathrm{O}_{2}$ substrate (R\&D Systems, Minneapolis, MN) for $20 \mathrm{~min}$. The $\mathrm{OD}_{450}$ was read using a Microplate reader (Bio-Rad Laboratories, Hercules, CA). The amount of cytokine was determined using an appropriate cytokine-specific standard curve.

For intracellular cytokine expression analysis, spleen cells of recipient treated with mAbs were stimulated with mitomycin C-treated allogeneic $(B A L B / c)$ or syngeneic (B6) mouse splenocytes and allowed to rest for $48 \mathrm{~h}$. Cells were stained with FITC-conjugated Ab to CD8 and PE-Cy5-conjugated $A b$ to CD69 and were then fixed and permeabilized using Cytofix/perm reagent (BD pharmingen, SanDiego, CA). Subsequently, these cells were stained with PE-labeled specific anti-IFN- $\gamma$, washed, and analyzed in a FACS analyzer as described above.

\section{Data analyses}

Actuarial curves of graft survival were compared by the log rank test. Other statistical analyses used the unpaired Student $t$ test. In all test procedures, probabilities $P<0.05$ were considered statistically significant.

\section{Results}

\section{Proportion of splenocyte-derived $\mathrm{CD} 4^{+} / \mathrm{CD} 8^{+} \mathrm{T}$ cells}

The proportion of splenocyte-derived $\mathrm{CD}^{+}$and $\mathrm{CD}^{+} \mathrm{T}$ cells in recipient C57BL/6 mice treated with mAb on days 10 and 22 posttransplant was shown in Table 1. On day 22 posttransplant, the two-signal blockade-treated group showed higher levels of proportion of $\mathrm{CD} 4^{+} \mathrm{T}$ cells than the groups receiving anti-CD45RB or anti-CD154 alone, or in combination with CTLA4-Ig. The two-signal blockade exerted potent effects on the proportion of $\mathrm{CD} 8^{+} \mathrm{T}$ cells and resulted in the significantly $(P<0.05)$ decreased levels of $\% \mathrm{CD}^{+} \mathrm{T}$ cells when compared with the groups untreated or treated with anti-CD154 or CTLA4-Ig alone, and their combination on days 10 and 22 posttransplant. It seemed that the groups receiving anti-CD45RB alone or with other $\mathrm{mAb}$ (anti-CD154 or CTLA4-Ig) had reduced proportion of 
Table 1. The proportions of splenocyte-derived $\mathrm{CD} 4^{+}$and $\mathrm{CD} 8^{+} \mathrm{T}$ cells in recipient C57BL/6 mice treated with mAb on days 10 and 22 posttransplant (each group had $n=4$ ).

\begin{tabular}{ccccccccc}
\hline & & Rat IgG & CTLA-4 Ig & Anti-CD154 & Anti-CD45RB & $\begin{array}{c}\text { CTLA-4 lg } \\
+ \text { anti-CD154 }\end{array}$ & $\begin{array}{c}\text { CTLA-4 Ig } \\
+ \text { anti-CD45RB }\end{array}$ & $\begin{array}{c}\text { Anti-CD154 } \\
\text { anti-CD45RB }\end{array}$ \\
\hline \% CD4 ${ }^{+}$ & Day 10 & $20.3 \pm 2.55$ & $25.0 \pm 4.56$ & $22.3 \pm 0.21$ & $24.1 \pm 0.72$ & $25.4 \pm 5.58$ & $31.7 \pm 6.44$ & $29.3 \pm 6.95$ \\
& Day 22 & $25.7 \pm 5.30$ & $24.8 \pm 3.76$ & $23.1 \pm 3.47^{\mathrm{a}}$ & $22.1 \pm 3.84^{\mathrm{a}}$ & $23.2 \pm 2.66^{\mathrm{a}}$ & $23.1 \pm 3.33^{\mathrm{a}}$ & $28.7 \pm 2.75^{\mathrm{b}}$ \\
$\% \mathrm{CD}^{+}$ & Day 10 & $19.5 \pm 1.67^{\mathrm{c}}$ & $12.8 \pm 1.43^{\mathrm{c}}$ & $11.5 \pm 2.58^{\mathrm{c}}$ & $9.0 \pm 2.51$ & $12.8 \pm 3.44^{\mathrm{c}}$ & $6.4 \pm 2.06$ & $5.7 \pm 1.59^{\mathrm{d}}$ \\
& Day 22 & $15.9 \pm 3.36^{\mathrm{e}}$ & $15.9 \pm 1.99^{\mathrm{e}}$ & $14.3 \pm 1.13^{\mathrm{e}}$ & $9.3 \pm 0.87$ & $13.2 \pm 1.96^{\mathrm{e}}$ & $9.4 \pm 0.86$ & $7.5 \pm 1.24^{\mathrm{f}}$ \\
\hline
\end{tabular}

Proportion of splenocyte-derived $\mathrm{CD}^{+}$and $\mathrm{CD} 8^{+} \mathrm{T}$ cells in recipient mice treated with $\mathrm{mAb}$ was measured using a flow cytometer. The data represent mean $\pm S D$ for each group. $a, b, c, d, e, f$ indicate $P<0.05$ ( $a$ vs $b, c$ vs $d$, e vs f) between the groups on each day.

$\mathrm{CD}^{+} \mathrm{T}$ cells in their spleens on days 10 and 22 posttransplant. The results indicate that the twosignal blockade and even anti-CD45RB alone have inhibitory effects on $\mathrm{CD}^{+} \mathrm{T}$ cells in spleens of recipients with skin allograft.

\section{CFSE assay in vivo}

We further tested whether the two-signal blockade would suppress allogeneic responses of recipient $\mathrm{CD}^{+}$or $\mathrm{CD}^{+} \mathrm{T}$ cells to donor cells in vivo. As shown in Figure $1 \mathrm{~A}, 1 \mathrm{~B}$, adoptively transferred splenocyte-derived $\mathrm{CD}^{+}$or $\mathrm{CD}^{+} \mathrm{T}$ cells labeled with CFSE displayed different patterns of proliferation. The figures (Figure $1 C$ and $D$ ) could be depicted from the frequency of precursors with more than 4 division based on the above histograms. $\mathrm{CD}^{+} \mathrm{T}$ cells of recipients treated with the two-signal blockade proliferated more $(1.23 \pm 0.165 \%, P<0.05)$ than those of recipients treated with CTLA-4-lg alone $(0.44 \pm 0.117 \%)$ or plus anti-CD154 $(0.46 \pm 0.056 \%)$ (Figure $1 \mathrm{C}$ ). In marked contrast, the proliferating activities of $\mathrm{CD}^{+} \mathrm{T}$ cells were significantly reduced in the two-signal blockade-treated group $(0.16 \pm$ $0.025 \%$ ) when compared with the groups having no therapy $(2.17 \pm 0.288 \%)$ or therapies of anti-CD154 $(0.97 \pm 0.067 \%)$ or CTLA4-lg alone $(0.73 \pm 0.176 \%)$ or their combination $(0.76 \pm 0.117 \%)$. Anti-CD45RB alone appeared to be very effective in suppressing allogeneic responses of $\mathrm{CD}^{+} \mathrm{T}$ cells when compared with the groups without anti-CD45RB treatment. It was demonstrated in vivo that the two-signal blockade or even anti-CD45RB alone can effectively control the proliferating activities of $\mathrm{CD}^{+} \mathrm{T}$ cells in murine allogeneic skin transplantation model.

\section{Proportion of effector/regulatory $\mathrm{T}$ cells}

The proportion of $\mathrm{CD} 4^{+} \mathrm{CD} 45 \mathrm{RB} \mathrm{B}^{\text {high }} \mathrm{T}$ cells among the groups was compared after analyzing dotplots and histograms (Figure 2A) obtained by flow cytometry as shown in Figure $2 \mathrm{~B}$. It was noted that the two-signal blockade and even anti-CD45RB alone or with CTLA4-Ig significantly $(P<0.05)$ reduced the proportion $C D 4^{+}$CD45RB ${ }^{\text {high }} \mathrm{T}$ cells on days 10 and 22 posttransplant in comparison to the other groups. The levels $(4.15 \pm 1.485 \%$ and $5.62 \pm 0.777 \%$ for days 10 and 22, respectively) observed in the group treated with the two-signal blockade were maintained in contrast to the increasing levels of the groups treated with anti-CD45RB alone or with CTLA4-Ig over the period of experiment time. The levels of $\%$ CD $4^{+} C D 45 R B^{\text {high }} T$ cells in spleens of recipients receiving CTLA4-Ig or anti-CD154 alone and their combination did not show marked changes when compared between day 10 and day 22 posttransplant. As a result, anti-CD45RB alone or with CTLA4-Ig or anti-CD154 have inhibitory effects on CD $4^{+} C D 45 R^{\text {high }}$ effector $T$ cells on days 10 and 22 after allogeneic skin transplantation.

We further determined frequency of donor-specific IFN- $\gamma$-producing cells in spleens of recipients as shown in Figure 2C and D. Anti-CD45RB plus CTLA4- Ig or anti-CD154 and costimulation blockade (CTLA4-Ig plus anti-CD154) suppressed IFN- $\gamma$ production by donor-specific splenocytes in contrast to a singular use of monoclonal antibody or nontreatment group on day 10 posttransplant (Figure 2C). On day 22 posttransplant, the levels of IFN- $\gamma$ producing cell number in all groups were reduced in comparison with those on day 10 posttransplant (Figure 2D). For instance, IFN- $\gamma$-producing cell number (501 cells $/ 10^{5}$ splenocytes) in the control group (non-treatment group) on day 10 was approximately one fourth less than that ( 129 cells $/ 10^{5}$ splenocytes) on day 22. It was strikingly noted that the group treated with the two-signal blockade steadily had great suppressive effects on IFN- $\gamma$ production, resulting in very low number ( 3 cells $/ 10^{5}$ splenocytes) of donor-specific IFN- $\gamma$-producing splenocytes. However, anti-CD45RB alone was not effective in suppression of IFN- $\gamma$ - producing cells on day 10 and 22 . The results indicate that the two-signal blockade 
A
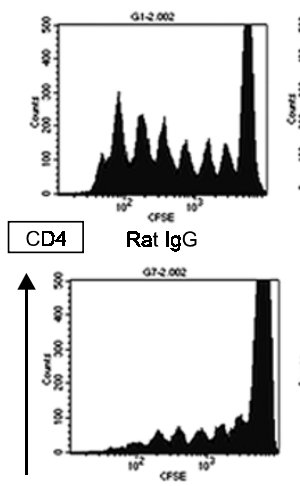

CTLA4-Ig

$+\alpha$-CD154

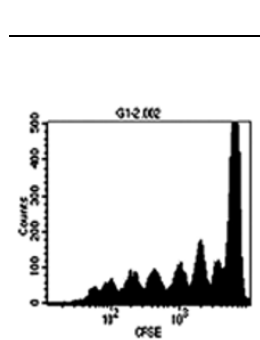

CD8 Rat IgG

B

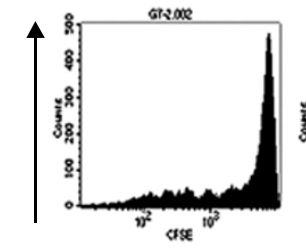

CTLA4-lg $+\alpha$-CD154
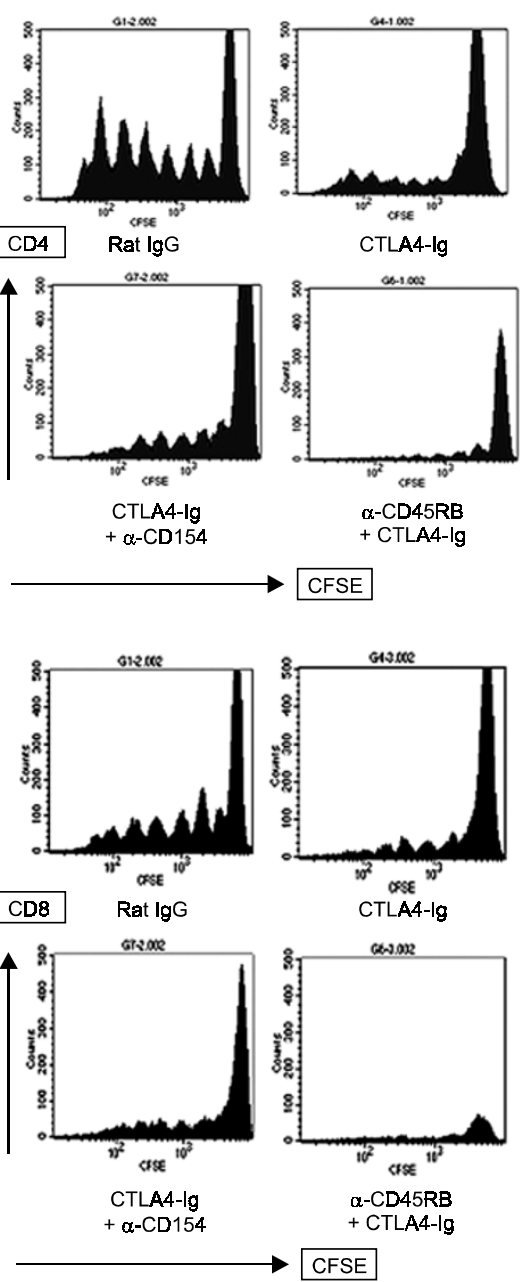

CTLA4-Ig
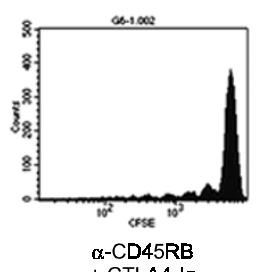
CFSE
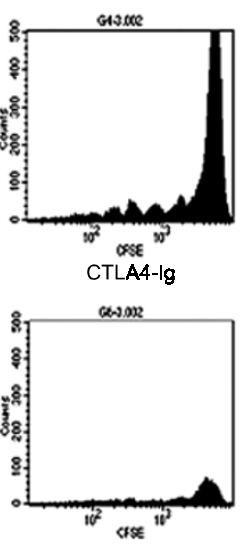

$\alpha$-CD45RB

$\alpha-C D 45 R B$
+ CTLA4-Ig

CFSE

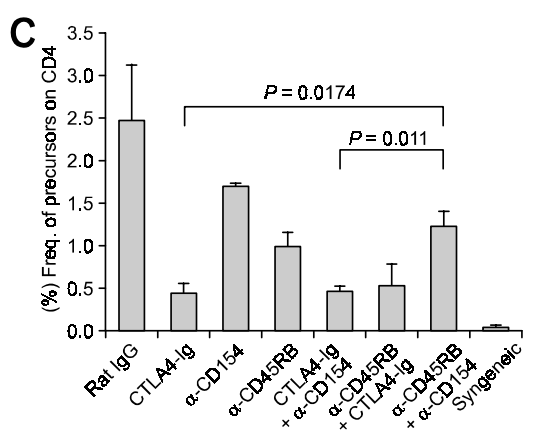

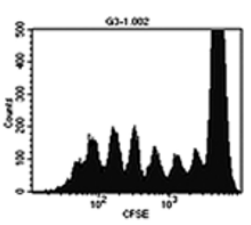
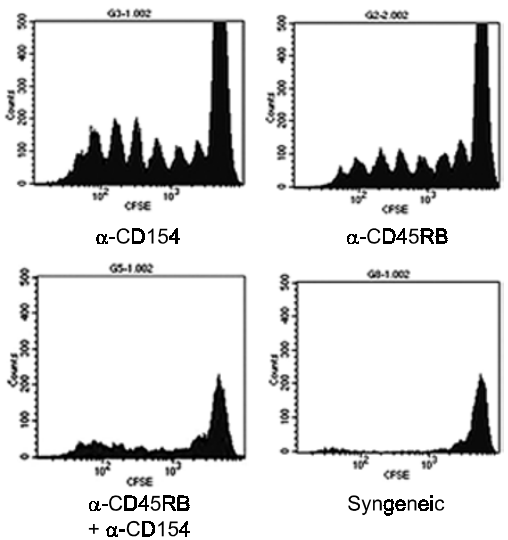

Syngeneic

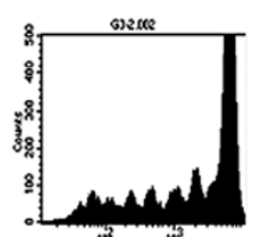

${ }^{n-\operatorname{Cos} \varepsilon^{2}}{ }^{10^{3}}$

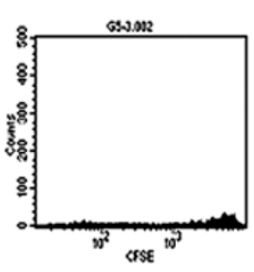

$\alpha-C D 45 R B$

$\alpha-C D 45 R B$
$+\alpha-C D 154$

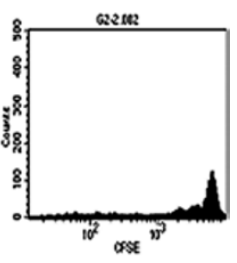

$\alpha$-CD45RB

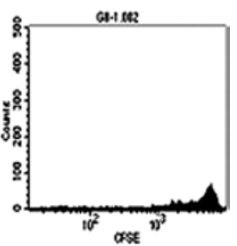

Syngeneic

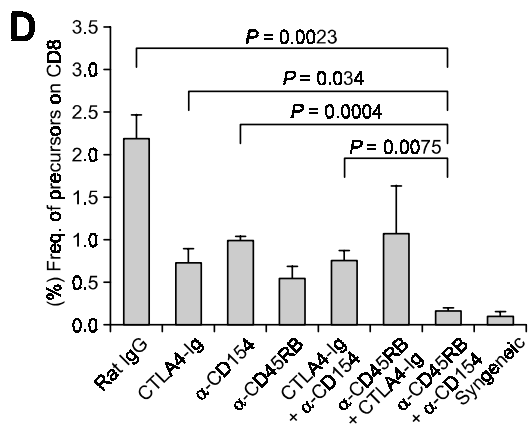

Figure 1. Allogeneic response of recipient $\mathrm{CD4}^{+}$or $\mathrm{CD} 8^{+} \mathrm{T}$ cells in vivo (each group had $n=3$ ). Splenocytes were obtained through C57BL/6 recipients untreated or treated with mAb on 10 day posttransplant and CFSE-labeling was performed as described in Materials and Methods. Irradiated $B A L B / C$ or C57BL/6 mice received $2 \times 10^{7}$ CFSE-labeled cells for allogeneic and syngeneic response, respectively. (A, B) Flow cytometric analysis for CFSE intensity and $\mathrm{CD4}^{+}(\mathrm{A})$ or $\mathrm{CD}^{+}(\mathrm{B})$ cells expression of live cells was performed at day 3 post-transfer. This is a representative example of three independent experiments. (C, D) Proliferating activities of $\mathrm{CD4}^{+}(\mathrm{C})$ or $\mathrm{CD}^{+}$(D) T cells. Precursor frequencies for divisions 4-8 are displayed in the $\mathrm{Y}$-axis (refer to Materials and Methods section). suppress donor-specific IFN- $\gamma$-producing cells in spleens of recipients with allograft and its suppressive effects were larger on day 22 than on day 10 posttransplant.

To test whether two-signal blockade influence expression of regulatory $T$ cells, we measured the percentage of $C D 4^{+} C D 45 R B^{\text {low }} T$ cells among the groups. As shown in Figure $2 \mathrm{E}$, there was a significant increase of $C D 4^{+} C D 45 R^{\text {low }} T$ cells in the two-signal blockade or anti-CD45RB-treated group relative to controls on day 8 posttransplant. The enhancement of $C D 4^{+} C D 45 R B^{\text {low }} T$ cells was only persisted in the two-signal blockade treated group at day 20 posttransplant. The results indicate that the two-signal blockade associates with increment of regulatory $T$ cells and prolongation of allograft survival due to diminished $C D 4^{+} C D 45 R^{\text {high }} T$ cells.

\section{Conversion of skin allograft survival through CD4 or CD8 $\mathrm{T}$ cells depletion}

We confirmed that survival of skin allograft was 
A

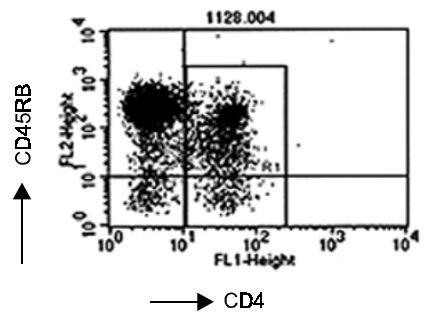

Rat $\lg G$
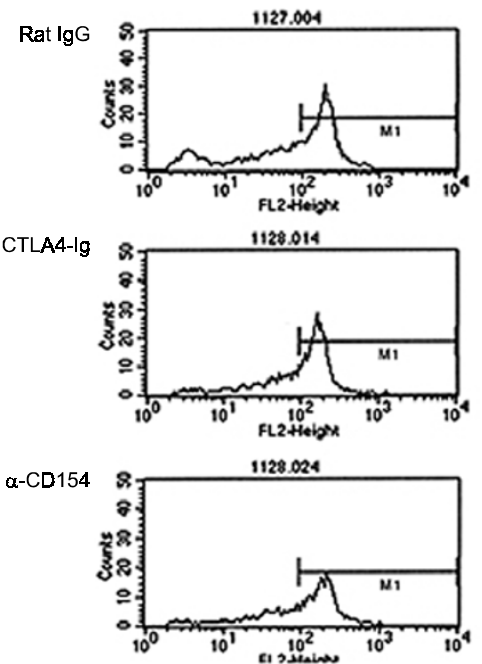

B

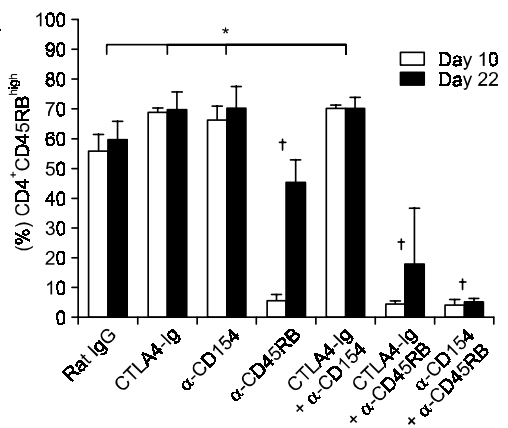

D

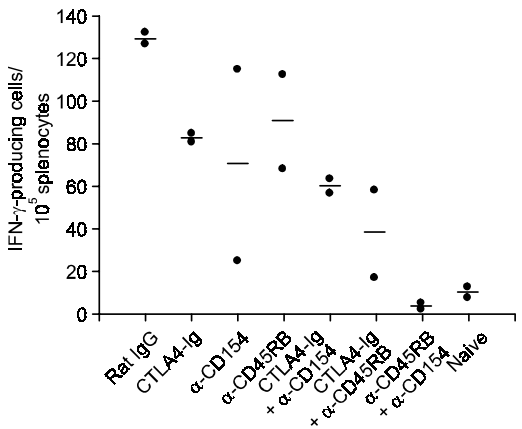

$\alpha-C D 45 R B$

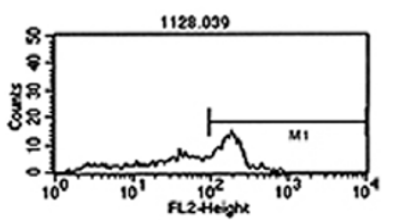

CTLA4-lg
$+\alpha-C D 154$

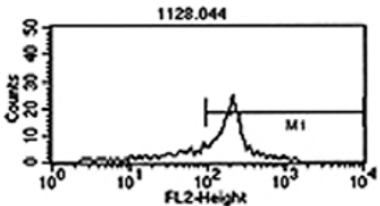

CTLA4-Ig

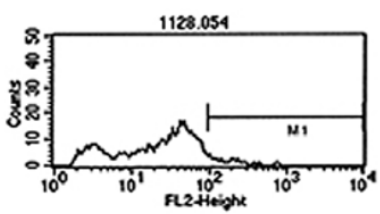
$\alpha-C D 154$
$+\alpha-C D 45 R B$

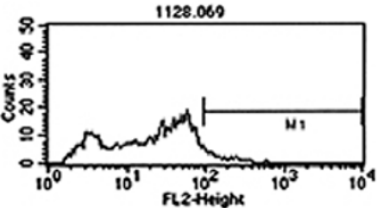

C

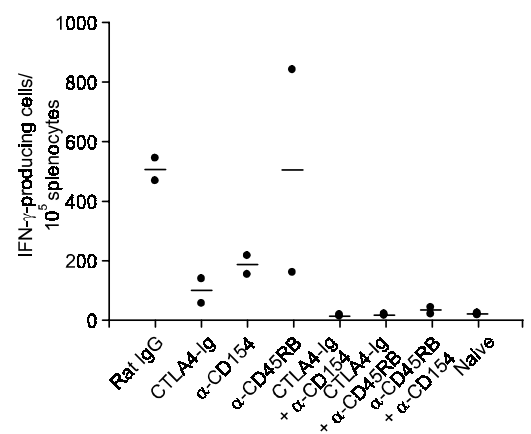

E

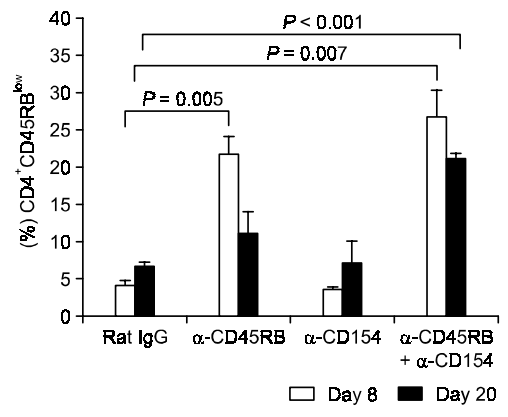

Figure 2. Proportion of splenocyte- derived effector/regulatory $T$ cells in recipient $\mathrm{C} 57 \mathrm{BL} / 6$ mice treated with $\mathrm{mAb}$ on days 10 and 22 posttransplant (each group had $n=4)$. (A, B) Proportion of $\mathrm{CD4}^{+} \mathrm{CD} 45 \mathrm{RB} \mathrm{B}^{\text {high }} \mathrm{T}$ cells diagramed in Figure $2 \mathrm{~A}$ and expressed as mean $\pm S D$ of four individual experiments in Figure $2 \mathrm{~B}$. $\mathrm{CD}^{+}$cells were gated as indicated R1 on a dot plot and analyzed for CD45RB high $T$ cells. Control indicates rat lgG-treated group. (C, D) Frequency of donor specific IFN- $\gamma$-producing cells in splenocytes of recipient C57BL/6 mice treated with $\mathrm{mAb}$ obtained at days $10(\mathrm{C})$ and 22 (D) posttransplant (each group had $n$ $=2$ ). Recipient splenocytes as effector cells were co-cultured with irradiated donor splenocytes as stimulator cells at 1:10 ratio of stimulators to effectors in ester-cellulose-bottom plates that had been precoated with $4 \mu \mathrm{g} / \mathrm{mL}$ anti-mouse IFN- $\gamma$ with/without stimulators. Frequency was determined by the dividing number of spots counted in each well by the total number of cells plated at that dilution. Y-axis represents the number of spots per $10^{5}$ Histopaque-separated leukocytes. Bars are displayed as the means of two independent experiments. (E) Percentage of $\mathrm{CD} 4^{+} \mathrm{CD} 45 \mathrm{RB}^{\text {low }}$ regulatory $\mathrm{T}$ cells in recipient $\mathrm{C} 57 \mathrm{BL} / 6$ mice treated with $\mathrm{mAb}$ obtained at days 8 and 20 posttransplant (each group had $n=3$ ). That expression was measured by flow cytometry. ${ }^{*},+$ indicate significant differences $(P<0.05)$ between the groups. markedly prolongated in the two-signal blockadetreated group. We further performed studies on the immunomodulatory effects of two-signal blockade (anti-CD45RB and anti-CD154) on $\mathrm{CD}^{+}$or $\mathrm{CD}^{+} \mathrm{T}$ cell dependence in a murine skin allograft model, where CD4 or CD8 depleted groups were used. The two-signal blockade plus CD4-depleting mAb-treated group showed acute rejection of skin. In contrast, CD8-depleting group treated with two-signal blockade resulted in prolongation of skin survival (MST of 


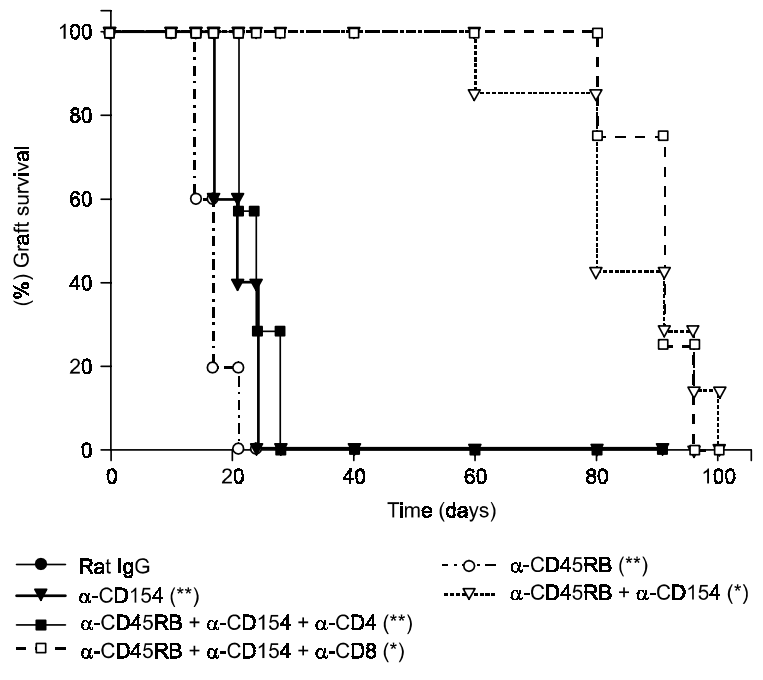

Figure 3. Skin allograft survival in mAb-treated recipients. Kaplan-Meir plot of cumulative allograft survival vs time. The skin allograft survival data was charted with the following recipient groups: control (rat lgG), $100 \mu \mathrm{g}(n=5)$; anti-CD45RB, $100 \mu \mathrm{g}(n=5)$; anti-CD154 (MR1), 250 $\mu \mathrm{g}(n=5)$; two-signal blockade with anti-CD45RB plus anti-CD154 i.p. on days $0,2,4,6$, and $8(n=8)$; two-signal blockade plus anti-CD4 $(100 \mu \mathrm{g})$ and two-signal blockade plus anti-CD8 $(100 \mu \mathrm{g})(n=7)$. Each $A b$ was used to deplete $T$ cells was administered on days $-2,-1$ and 0 before transplantation and given every week until the day of graft rejection. ${ }^{*}, P<0.001$ vs control; ${ }^{* *}, P<0.03$ vs two-signal blockade treated group.

90 days), as shown in the group treated with the two-signal blockade alone (Figure 3 ). This indicates that the two-signal blockade immunomodulates via $\mathrm{CD} 4^{+} \mathrm{T}$ cells.

\section{Changes through depletion of CD4 T cells}

We previously observed that percentage of $C D 8^{+} \mathrm{T}$ cells in anti-CD45RB plus anti-CD154 group decreased rather than in the control group. Next, we tested to see whether the depletion of CD4 T cells in the group treated with the two-signal blockade was associated with changes in $\mathrm{CD}^{+} \mathrm{T}$ cells. We found a significant increase in the percentage of $\mathrm{CD}^{+} \mathrm{T}$ cells in CD4-depleted group treated with antiCD45RB plus anti-CD154 relative to the group treated with the two-signal blockade (Figure 4A). Because low levels or no expression of CD62L is correlated with the effector/memory phenotype, we subsequently examined CD62L low and IFN- $\gamma$-secreting $\mathrm{CD}^{+} \mathrm{T}$ cells in each group. The proportion of $\mathrm{CD} \mathrm{L}^{\text {low }}$ and IFN- $\gamma$-secreting $\mathrm{CD}^{+} \mathrm{T}$ cells in the two-signal blockade treated group were decreased when compared with the control group while CD4-depleted group treated with the two-signal blockade showed increased proportions of CD62L low and IFN- $\gamma$-secreting $\mathrm{CD}^{+} \mathrm{T}$ cells when compared with the two-signal blockade group (Figure 4B). Furthermore, we investigated the expression of CTLA-4 which down-modulates $T$ cell response and promote allograft survival on $\mathrm{CD}^{+} \mathrm{T}$ cells. The expression of $\mathrm{CD} 8^{+} \mathrm{CTLA}-4$ was up-regulated by the two-signal blockade when compared with the control group; however, the expression of CD8 ${ }^{+}$CTLA-4 was significantly decreased in CD4-depleted group treated with the two-signal blockade (Figure 4C). Thus, we were verified that immunomodulatory effects by two-signal blockade influenced CD8 T cells through $\mathrm{CD}^{+} \mathrm{T}$ cells.

On the basis of our finding that anti-CD45RB plus anti-CD154 treatments cause a significant decrease in proliferation frequency and proportion of IFN- $\gamma$ producing $\mathrm{CD}^{+} \mathrm{T}$ cells when compared with the control, anti-CD154 alone treatment, we next tested to determine whether CD4-depleted group treated with two-signal blockade influences cytokine profiles. In CD4-depleted group treated with two-signal blockade, expression level of IFN- $\gamma$ was increased while those of IL-4 and IL-10 were down-regulated when compared with two-signal blockade treated group (Figure 4D and E). Moreover, results of IFN- $\gamma$ on ELISA showed as such significant increase of IFN- $\gamma$ secreting effector $\mathrm{CD}^{+} \mathrm{T}$ cells in CD4-depleted group. This indicates that the two-signal blockade requires $\mathrm{CD}^{+} \mathrm{T}$ cells for immunomodulation.

\section{Discussion}

Costimulation blockade with anti-CD154 plus CTLA4Ig has been accepted for blocking $T$ cell activation and inhibiting allograft rejection effectively; however, it does not always produce indefinite graft survival in the stringent skin transplantation model with certain strains of mice (Trambley J et al., 1999). Inclusions of anti-CD45RB in therapy with anti-CD154 overcome this limitation of costimulation blocker, showing effectiveness in promoting long term engraftment and tolerance (Rothstein DM et al., 2001). These results are also confirmed in our systems.

CD45RB, as a target molecule of anti-CD45RB, is expressed in a cell type, development stage, and activation state dependent manner (Hermiston $\mathrm{ML}$ et al., 2003). We previously observed that CD45RB is much more highly expressed by $\mathrm{CD} 8^{+} \mathrm{T}$ cells and $\mathrm{B}$ cells than $\mathrm{CD}^{+} \mathrm{T}$ cells and granulocytes in various wild types (BALB/c, C57BL/6, C3H) of mice (data not shown). The high expression of CD45RB on these types of cells would be associated with the predominant expression of CD45RB on naive peripheral $T$ cells and memory B cells (Hermiston ML et al., 2003). High degrees of CD45RB expression on $\mathrm{CD}^{+} \mathrm{T}$ cells might expedite the chances of anti- 
A
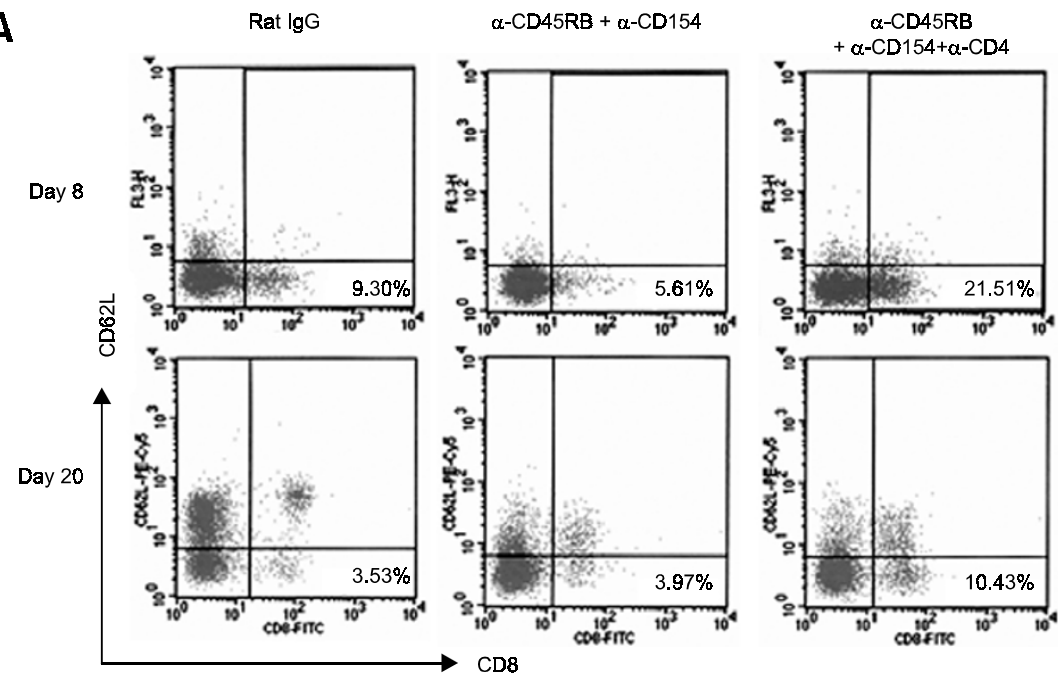

B

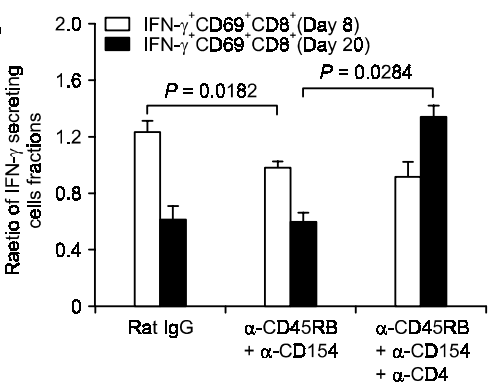

D

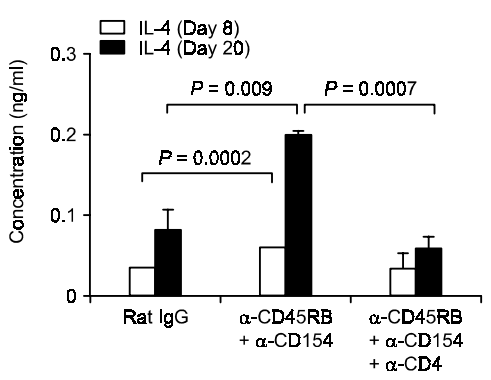

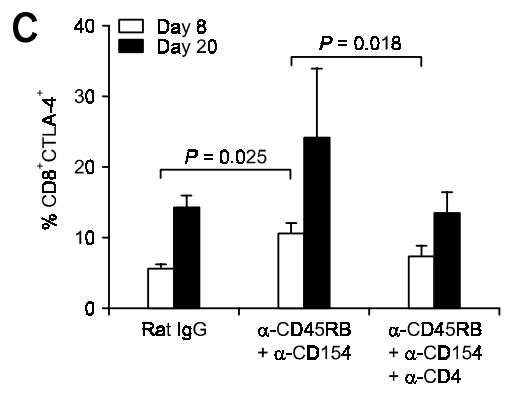

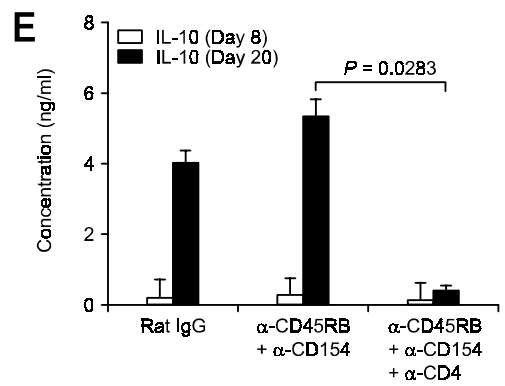

Figure 4. Changes of $C D 8^{+} T$ cells in splenocytes of mAb-treated recipient C57BL/6 mice (each group had $n=3$ ). (A) Proportion of $\mathrm{CD}^{+}{ }^{+}$D62 $\mathrm{L}^{\text {low }} \mathrm{T}$ cells in recipient $\mathrm{C} 57 \mathrm{BL} / 6$ mice treated with $\mathrm{mAb}$ obtained at days 8 and 20 posttransplant. That percentage was acquired by immunofluorescence staining and flow cytometry. (B) Proportion of $\mathrm{CD} 8^{+}$ $\mathrm{CD} 69^{+} \mathrm{IFN}-\gamma^{+}$effector $\mathrm{T}$ cells in recipient $\mathrm{C} 57 \mathrm{BL} / 6$ mice treated with $\mathrm{mAb}$ obtained at days 8 and 20 posttransplant. Splenocytes (1 $\times 10^{5}$ ) of recipient treated with $\mathrm{mAb}$ were stimulated with mitomycin C-treated allogeneic (BALB/C) or syngeneic (C57BL/6) mouse splenocytes $\left(1 \times 10^{5}\right)$ and allowed to rest for $48 \mathrm{~h}$. FACS density plots are shown based in $\mathrm{CD}^{+}$gating with $\mathrm{CD} 69$ and IFN- $\gamma$ staining. The percentages represent the percentages of $\mathrm{CD}^{+}$cells with the $\mathrm{CD} 69^{+}$IFN- $\gamma^{+}$ phenotype. Ratio between the relative fractions of IFN- $\gamma$-secreting effector $\mathrm{CD} 8^{+} \mathrm{T}$ cells, determined according to the following equation: [Allogenecic response (\%) / Syngeneic response (\%)]. (C) Proportion of CD8 ${ }^{+}$CTLA$4^{+}$regulatory cells in splenocytes of recipient treated with mAb showed using flow cytometric analysis. (D, E) Cytokine profiles of splenocytes in recipient $\mathrm{C} 57 \mathrm{BL} / 6$ mice treated with $\mathrm{mAb}$ obtained at days 8 and 20 posttransplantation (each group had $n=3$ ). Splenocytes $\left(2 \times 10^{5}\right)$ were cultured in 200 $\mu \mathrm{L}$ RPMI1640 medium supplemented with $10 \%$ FBS and $2 \mu \mathrm{g} / \mathrm{mL}$ anti-CD28 in 96-well plates that had been precoated with $5 \mu \mathrm{g} / \mathrm{mL}$ anti-CD3 for $72 \mathrm{~h}$. Cytokine concentration in the culture supernatants was measured by ELISA.
CD45RB to bind and to affect $\mathrm{CD}^{+} \mathrm{T}$ cells. In our experimental model, the use of anti-CD45RB in combination with anti-CD154 resulted in the reduced proportion of splenocyte-derived $\mathrm{CD}^{+} \mathrm{T}$ cells in recipients with allograft on days 10 and 22 posttransplant. Additionally, we assured that the absolute number of splenocyte-derived $\mathrm{CD}^{+} \mathrm{T}$ cells did not differ significantly among the experimental groups in our studies, while that of $\mathrm{CD}^{+} \mathrm{T}$ cells in the group treated with the two-signal blockade was significantly diminished as compared with control group (data not shown). This result is consistent with the reduced proportion of $\mathrm{CD}^{+} \mathrm{T}$ cells in the previous study (Table 1); therefore, it would be inferred that decreased proliferating activities of $\mathrm{CD}^{+} \mathrm{T}$ cells in response to alloantigens of skin are closely asso- ciated with their existence at low proportion in spleens of recipients with prolonged survival of skin allograft. It was found in additional studies that the allogeneic responses of $\mathrm{CD} 8^{+} \mathrm{T}$ cells in vivo on day 10 posttransplant are effectively suppressed by the two-signal blockade. In marked contrast, the twosignal blockade caused an increase in the proportion of $\mathrm{CD}^{+} \mathrm{T}$ cells on days 10 and 22 posttransplant despite a similar absolute number of $C D 4^{+} \mathrm{T}$ cells among the experimental groups. The frequency of proliferating $\mathrm{CD}^{+} \mathrm{T}$ cells in recipients with two-signal blockade was significantly increased in comparison to the groups receiving CTLA-4 Ig alone or with anti-CD154, which was similar to the results of proportion shown in Table 1. We hypothesized that this increasing pattern of proliferation and proportion 
in $\mathrm{CD}^{+} \mathrm{T}$ cells would be related to generation of regulatory $T$ cells which are requisite components to prevent rejection and to maintain peripheral tolerance. This hypothesis may be supported by the results of our studies where the proportion of regulatory $\mathrm{T}$ cells, $\mathrm{CD}^{+} \mathrm{CD} 45 \mathrm{RB}{ }^{\text {low }}$ cells, was significantly increased in spleens of the groups treated with the two-signal blockade when compared with the control group as observed by Molano's group in islet transplantation (Molano RD et al., 2003) (Figure $2 \mathrm{E})$. The two-signal blockade sustained their effects showing augmented levels of $C D 4^{+} C D 45 R B^{\text {low }} T$ cell proportion on day 20 posttransplant. On the other hand, decreased proportion of $C D 4^{+} C D 45 R^{\text {high }} T$ cells which have been known as effector cells capable of promoting rejection was accompanied by increased proportion of $C D 4^{+} C D 45 R B^{\text {low }} \mathrm{T}$ cells. Anti-CD45RB might cause shift from CD45RB ${ }^{\text {high }}$ to CD45RB ${ }^{\text {low }}$ cells by way of cell surface CD45RB down-regulation in agreement with the results as shown in Basadonna et al (Basadonna et al., 1998). However, it was proposed that anti-CD45RB selectively kill CD45RB ${ }^{\text {high }}$ cells, leaving a dominant $\mathrm{CD}^{2} \mathrm{RB}^{\text {low }}$ population of $\mathrm{T}$ cells (Groux $\mathrm{H}$ et al., 1997). We need study more to understand clear causes of these results. There are findings that increase in $\mathrm{CD}_{45 \mathrm{RB}}{ }^{\text {low }}$ expression was associated with a 2 -fold increase in the number of $\mathrm{CD} 4^{+}$cells expressing CTLA-4, raising the possibility that antiCD45RB act through CTLA-4 up-regulation (Fecteau $S$ et al., 2001). So we tried to observe up-regulated CTLA-4 expression by anti-CD45RB, therefore, we identified that CTLA-4 expression on $\mathrm{CD}^{+} \mathrm{T}$ cells in anti-CD45RB treated group were higher than that in non-treated groups (Figure 4C). However, CTLA-4 expression on $\mathrm{CD}^{+}{ }^{+} \mathrm{T}$ cells was not statistically different between the groups in our studies (Data not shown).

IFN- $\gamma$ is an immunoregulatory cytokine secreted by activated T and NK cells (Boehm U et al., 1997). It is therefore postulated that IFN- $\gamma$ mediates acute transplant rejection while IFN- $\gamma$ neutralization favors long-term engraftment (Sayegh $\mathrm{MH}$ et al., 1995). It was demonstrated that anti-CD45RB treatment markedly inhibited expression of Th1 cytokines such as IFN- $\gamma$ and IL-2 (Sutherland RM et al., 2002). In our studies, anti-CD45RB alone appeared to be ineffective in suppressing IFN- $\gamma$-producing cells as determined by ELISPOT assay although the frequency of IFN- $\gamma$-producing cells was lower than that in untreated group. However, the combined use of antiCD45RB with anti-CD154 suppressed donor-specific IFN- $\gamma$-producing cells on days 10 and 22 posttransplant. This down-regulation of IFN- $\gamma$ production may partly result from inhibited proliferation and reduced proportion of $\mathrm{CD} 8^{+} \mathrm{T}$ cells because IFN- $\gamma$ is produced by $\mathrm{CD} 8^{+} \mathrm{T}$ cells for effector function (Seder RA et al., 2003). In addition, expression of $\mathrm{CD}^{+}{ }^{-}$ CD62L low cells related to effector/memory cells were also appeared diminishment in anti-CD45RB treated group more than in non-treated groups. In summary, we observed that two-signal blockade resulted in inhibition of effector cells including $C D 4^{+} C D 45 R B^{\text {high }}$ and IFN- $\gamma$-producing cells and increment of regulatory $T$ cells $\left(C D 4^{+} C D 45 R^{\text {low }}\right.$ ) in a murine allogeneic skin transplantation model.

Also, we performed depletion studies with mAb (anti-CD4 and anti-CD8) to test CD4 or CD8 T cell dependence on effect of two-signal blockade (Yuan Zhai et al., 2003). Absence state of $\mathrm{CD}^{+} \mathrm{T}$ cells resulted in acute rejection compared with two-signal blockade treated recipients in skin transplantation. In contrast, depletion of $\mathrm{CD}^{+} \mathrm{T}$ cells in two-signal blockade treated recipients did not influence graft survival. Furthermore, the groups receiving antiCD45RB, anti-CD154 alone or with depletion mAb (anti-CD4 or anti-CD8) was relatively ineffective in prolonging skin graft survival in this immunogeneic strain combination (data not shown). Also, depletion of $\mathrm{CD}^{+} \mathrm{T}$ cells with two-signal blockade induced a shift of phenotypes, absolute number and cytokine profiles. In other words, condition of $\mathrm{CD}^{+} \mathrm{T}$ cells depletion result in recovery from immunoregulatory effects of two-signal blockade. These phenomena corresponded to data of allograft survival. These findings are in agreement with other studies, where regulatory $\mathrm{T}$ cells have specially been implicated in the induction and maintenance of transplantation tolerance. The recovery from immunomodulatory effects of two-signal blockade would be inferred because depletion of $\mathrm{CD}^{+} \mathrm{T}$ cells would lead to absence of $\mathrm{CD}^{+} \mathrm{CD} 45 \mathrm{RB} \mathrm{B}^{\text {low }}$ regulatory $\mathrm{T}$ cells, moreover, reaction of $\mathrm{CD} 8^{+} \mathrm{T}$ cells required $\mathrm{CD} 4^{+} \mathrm{T}$ cells. In addition, it has been shown recently that nonspecific $T$ cell depletion using depleting $\mathrm{mAb}$ occur homeostatic proliferation. This process may induce acquisition of functional effector/memory $T$ cells. In this case, costimulatory blockade neither significantly suppresses homeostatic proliferation nor prevents allograft rejection (Zihao et al., 2004; David et al., 2006). The data in this study show that proportion of $\mathrm{CD} 8{ }^{+} \mathrm{CD} 62 \mathrm{~L}^{\text {low }}$ memory cells increased in CD4- depleted group treated with the two-signal blockade compared with two-signal blockade group. This finding is consistent with recent studies of homeostatic proliferation. However, our result displayed that simultaneously enhanced IFN- $\gamma$-producing $\mathrm{CD}^{+} \mathrm{T}$ cells. It is suggested that arose homeostatic expansion of effector/memory $T$ cells being capable of immediate effector functions using CD4-depleting mAb with two-signal blockade in our model. Moreover, our result that the two-signal 
blockade plus CD4-depleting mAb decreased expression of $\mathrm{CD} 8^{+} \mathrm{CTLA}-4$ regulatory $\mathrm{T}$ cells correlate with the previous report that homeostatic proliferation reduced by regulatory cells (Shiqian Shen et al., 2005; David et al., 2006).

In conclusion, the two-signal blockade can modulate $T$ cells, including donor-specific effectors and regulatory cells, and lead to suppressed allogeneic immune responses and prolonged skin allograft in a murine skin transplantation model. This study demonstrated that the two-signal blockade directly affects by $\mathrm{CD}^{+} \mathrm{T}$ cells and lead to influence on $\mathrm{CD}^{+} \mathrm{T}$ cells. Therefore, the immunomodulatory effects of the two-signal blockade show inhibition of $\mathrm{CD}^{+} \mathrm{T}$ cells via CD4-dependent mechanism.

\section{Acknowledgment}

This research was supported by grants from the IN-SUNG Foundation for Medical Research, Seoul, Korea (C-A5-810-1).

\section{References}

Auersvald LA, Rothstein DM, Oliveira SC, Khuong CQ, Onodera H, Lazarovits Al, Basadonna GP. Indefinite islet allograft survival in mice after a short course of treatment with anti-CD45 monoclonal antibodies. Transplantation 1997;63: 1355-8

Basadonna GP, Auersvald L, Khuong CQ, Zheng XX, Kashio N, Zekzer D, Minozzo M, Qian H, Visser L, Diepstra A, Lazarovits AI, Poppema S, Strom TB, Rothstein DM. Antibody-mediated targeting of CD45 isoforms: a novel immunotherapeutic strategy. Proc Natl Acad Sci USA 1998;95: 3821-6

Boehm U, Klamp T, Groot M, Howard JC. Cellular responses to interferon. Annu Rev Immunol 1997;15:749-95

Davies JD, O'Connor E, Hall D, Krahl T, Trotter J, Sarvetnick N. CD $4^{+} C D 45 R B$ low-density cells from untreated mice prevent acute allograft rejection. J Immunol 1999;16310:5353-7

Fecteau S, Basadonna GP, Freitas A, Ariyan C, Sayegh MH, Rothstein DM. CTLA-4 up-regulation plays a role in tolerance mediated by CD45. Nat Immunol 2001;2:58-63

Groux H, O'Garra A, Bigler M, Rouleau M, Antonenko S, de Vries JE, Roncarolo MG. A CD4 ${ }^{+}$T-cell subset inhibits antigen-specific T-cell responses and prevents colitis. Nature 1997;389:737-42

Hathcock KS, Laszlo G, Dickler HB, Sharrow SO, Johnson P, Trowbridge IS, Hodes RJ. Expression of variable exon A-, B-, and $\mathrm{C}$-specific CD45 determinants on peripheral and thymic T cell population. J Immunol 1992;148:19-28

Hermiston ML, Xu Z, Weiss A. CD45: A critical regulator of signaling thresholds in immune cells. Annu Rev Immunol 2003;21:107-37

Kenyon NS, Chatzipetrou M, Masetti M, Ranuncoli A, Oliveira
M, Wagner JL, Kirk AD, Harlan DM, Burkly LC, Ricordi C. Long-term survival and function of intrahepatic islet allografts in rhesus monkeys treated with humanized anti-CD154. Proc Natl Acad Sci USA 1999;96:8132-7

Kenyon NS, Fernandez LA, Lehmann R, Masetti M, Ranuncoli A, Chatzipetrou M, laria G, Han D, Wagner JL, Ruiz P, Berho $M$, Inverardi L, Alejandro R, Mintz DH, Kirk AD, Harlan DM, Burkly LC, Ricordi C. Long-term survival and function of intrahepatic islet allografts in baboons treated with humanized anti-CD154. Diabetes 1999;48:1473-81

Kim A, Noh YW, Kim KD, Jang YS, Choe YK, Lim JS. Activated natural killer cell-mediated immunity is required for the inhibition of tumor metastasis by dendritic cell vaccination. Exp Mol Med 2004;36:428-43

Kirk AD, Harlan DM, Armstrong NN, Davis TA, Dong Y, Gray GS, Hong X, Thomas D, Fechner JH Jr, Knechtle SJ. CTLA-lg and anti-CD40 ligand prevent renal allograft rejection in primates. Proc Natl Acad Sci USA 1997;94:8789-94

Kirk AD, Burkly LC, Batty DS, Baumgartner RE, Berning JD, Buchanan K, Fechner JH Jr, Germond RL, Kampen RL, Patterson NB, Swanson SJ, Tadaki DK, TenHoor CN, White L, Knechtle SJ, Harlan DM. Treatment with humanized monoclonal antibody against CD154 prevents acute renal allograft rejection in non-human primates. Nat Med 1999;5:686-93

Lazarovits Al, Poppema S, Zhang Z, Khandaker M, Le Feuvre CE, Singhal SK, Garcia BM, Ogasa N, Jevnikar AM, White MH, Singh G, Stiller CR, Zhong RZ. Prevention and reversal allograft rejection by antibody against CD45RB. Nature 1996; 380:717-20

Molano RD, Pileggi A, Berney T, Poggioli R, Zahr E, Oliver R, Ricordi C, Rothstein DM, Basadonna GP, Inverardi L. Prolonged islet allograft survival in diabetic NOD mice by targeting CD45RB and CD154. Diabetes 2003;52:957-64

Neujahr DC, Chen C, Huang X, Markmann JF, Cobbold S, Waldmann H, Sayegh MH, Hancock WW, Turka LA. Accelerated memory cell homeostasis during $T$ cell depletion and approaches to overcome it. J Immunol 2006;176:4632-9

Rothstein DM, Livak MF, Kishimoto K, Ariyan C, Qian HY, Fecteau S, Sho M, Deng S, Zheng XX, Sayegh $M H$, Basadonna GP. Targeting signal 1 through CD45RB synergizes with CD40 ligand blockade and promotes long term engraftment and tolerance in stringent transplant models. J Immunol 2001;166:322-9

Sayegh MH, Akalin E, Hancock WW, Russell ME, Carpenter CB, Linsley PS, Turka LA. CD28-B7 blockade after alloantigenic challenge in vivo inhibits Th1 cytokines but spares Th2. J Exp Med 1995;181:1869-74

Seder RA, Ahmed R. Similarities and differences in $\mathrm{CD} 4^{+}$and $\mathrm{CD}^{+}$effector and memory $\mathrm{T}$ cell generation. Nat Immunol 2003;4:835-42

Shen S, Ding Y, Tadokoro CE, Olivares-Villagomez D, Camps-Ramirez M, Curotto de Lafaille MA, Lafaille JJ. Control of homeostatic proliferation by regulatory T cells. J Clin Invest 2005;115:3517-26

Sho M, Yamada A, Najafian N, Salama AD, Harada H, Sandner SE, Sanchez-Fueyo A, Zheng XX, Strom TB, Sayegh MH. Physiological mechanisms of regulating alloimmunity: cyto- 
kines, CTLA-4, CD25 ${ }^{+}$cells, and the alloreactive T cell clone size. J Immunol 2002;169:3744-51

Sung Hee Yoon, Hyun II Cho, Tai Gyu Kim. Activation of B cells using Schneider 2 cells expressing CD40 ligand for the enhancement of antigen presentation in vitro. Exp Mol Med 2005;37:567-74

Sutherland RM, McKenzie BS, Zhan Y, Corbett AJ, Fox-Marsh A, Georgiou HM, Harrison LC, Lew AM. Anti-CD45RB antibody deters xenograft rejection by modulating $T$ cell priming and homing. Int Immunol 2002;14:953-62

Tilney NL, Whitley WD, Diamond JR, Kupiec-Weglinski JW, Adams DH. Chronic rejection--an undefined conundrum. Transplantation 1991;52:389-98

Trambley J, Bingaman AW, Lin A, Elwood ET, Waitze SY, Ha J, Durham MM, Corbascio M, Cowan SR, Pearson TC, Larsen CP. Asialo $\mathrm{GM} 1^{+} \mathrm{CD} 8^{+} \mathrm{T}$ cells play a critical role in costimulation blockade-resistant allograft rejection. J Clin Invest 1999; 104:1715-22
Trowbridge IS, Thomas ML. CD45: an emerging role as a protein tyrosine phosphatase required for lymphocyte activation and development. Annu Rev Immunol 1994;12:85-116

Williams MA, Trambley J, Ha J, Adams AB, Durham MM, Rees $P$, Cowan SR, Pearson TC, Larsen CP. Genetic characterization of strain differences in the ability to mediate CD40/ CD28-independent rejection of skin allografts. J Immunol 2000;165:6849-57

Wu Z, Bensinger SJ, Zhang J, Chen C, Yuan X, Huang X, Markmann JF, Kassaee A, Rosengard BR, Hancock WW, Sayegh MH, Turka LA. Homeostatic proliferation is a barrier to transplantation tolerance. Nat Med 2004;10:87-92

Zhai Y, Meng L, Busuttil RW, Sayegh MH, Kupiec-Weglinski JW. Activation of alloreactive $\mathrm{CD}^{+} \mathrm{T}$ cells operates via CD4-dependent and CD4-independent mechanism and is CD154 blockade sensitive. J Immunol 2003;170:3024-8 